\title{
Plasma alkaline ribonuclease $(E C$ 3.1.4.22) and nitrogen retention in low-birth-weight infants
}

\author{
BY P. H. SCOTT, H. M. BERGER,* CAROLINE KENWARD, \\ P. SCOTT AND B. A. WHARTON \\ Biochemistry Department, Selly Oak Hospital, Birmingham B29 6JD, \\ and Sorrento Maternity Hospital, Moseley, Birmingham $\mathrm{BI} 39 \mathrm{HE}$
}

(Received 9 March 1978-Accepted 6 April 1978)

\begin{abstract}
I. Nitrogen retention was determined by classical $\mathrm{N}$ balance techniques in fourteen rapidly growing low-birth-weight infants receiving $3 \mathrm{~g}$ protein $/ \mathrm{kg}$ body-weight and during their 3 rd week of life. This was compared with plasma free alkaline ribonuclease (EC 3.1.4.22; RNase) activity and other biochemical measurements of protein nutrition.

2. Plasma RNase showed a significant positive correlation with $\mathbf{N}$ retention and a corresponding negative correlation with urine urea- $\mathrm{N}$. These results were unexpected and suggest a different relationship between RNase and $\mathbf{N}$ retention in infants compared with that found by other workers in children and adults.

3. The most likely explanation of this apparent anomaly is that in all instances high activities of plasma RNase are associated with a need to conserve $N$. In the infants studied this may indicate some measure of 'protein economy' and they could therefore benefit from a higher protein intake.
\end{abstract}

For many years, determination of nitrogen balance has been accepted as a classical technique for the assessment of protein status, protein requirements and biological value of proteins. The technique is difficult and inconvenient to perform, and consequently a large number of biochemical measurements have been examined in the hope of finding a satisfactory alternative. These include determinations of various plasma proteins, amino acids and enzymes, and the urinary excretion of $\mathrm{N}$-containing compounds. None has been completely successful though many prove useful in specific situations (Whitehead, I964; McFarlane, Ogbeide, Reddy, Adock, Adeshina, Gurney, Cooke, Taylor \& Modie, 1969; Arroyave, I970; Smith, Pozefsky \& Chhetri, I974).

Assessment of $\mathrm{N}$ balance in infants is particularly difficult because of the problems of separating urine from faeces and the supervision required. In view of recent studies showing that in children and adults changes in serum alkaline ribonuclease (EC 3.I.4.22; RNase) reflect inversely those changes occurring in $\mathrm{N}$ balance (Albanese, Orto, Zavattaro \& de Carlo, I97I ; Sigulem, Brasel, Velasco, Rosso \& Winnick, I973), this investigation was designed to examine the relationship in infants. At the same time serum RNase was compared with other biochemical indicators of protein metabolism.

\section{EXPERIMENTAL METHODS}

Outline of study

Fourteen low-birth-weight $(\mathrm{I} \cdot 8 \mathrm{o}-2 \cdot 26 \mathrm{~kg})$ infants were selected as subjects for study because their comparatively high rate of growth increases the demands on $\mathrm{N}$ metabolism. Nine were preterm (less than thirty-seven completed weeks gestational age) and five were term lightfor-dates. Their prolonged stay in hospital made possible investigation during the 2 nd and 3 rd weeks of life. Male infants (five Asian and four European) were chosen as most appropriate for the present studies. They were fed on either SMA or S26 (infant feeding formulas:

* Present address: Southmead Hospital, Bristol BS io 5 NB. 
John Wyeth Ltd, Maidenhead, Berks.) made up according to the manufacturers' instructions. The standard feeding schedule of the Premature Baby Unit was used so that all infants were receiving $200 \mathrm{ml} / \mathrm{kg}$ (i.e. 3 g protein and $563 \mathrm{~kJ} / \mathrm{kg}$ ) by the 9 th day.

On the Ioth day a $24 \mathrm{~h}$ urine collection was made and on the I Ith day $(4.25 \mathrm{~h}$ after the end of the last feed) a sample of blood was taken. $N$ retention was determined over a period of either 3 or $5 \mathrm{~d}$ during the 3 rd week, terminating on the 19 th day. The formulas for this period were prepared by one of us (H.M.B.) using the weight of the baby on day 13 for volume calculations. The individual feeds were then accurately measured by volume, poured into bottles and frozen until needed. A portion of each feed was retained for analysis. On the 2 Ist day a further blood sample was obtained. Throughout the study the infant's weight was measured using a Salter spring balance.

\section{Ethical considerations}

The plan of study (part of a larger project) was approved by the Hospital Research Committee and the informed consent to the investigations was obtained from the parents. Because of their low birth weight the infants were in the routine care of the Premature Baby Unit, Sorrento Maternity Hospital.

\section{Sample collection and preservation}

The blood samples were obtained by heel prick. They were centrifuged within $\mathrm{I} h$ and the plasma separated. For amino acid analysis $50 \mu \mathrm{l}$ portions were taken, to which were added $50 \mu 10.40 \mathrm{~mm}$-norleucine as internal standard and $200 \mu 1 \mathrm{ro0} \mathrm{mm}$-sulphosalicylic acid. After centrifugation the supernatant fractions were separated. These and the original plasma samples were stored at $-20^{\circ}$ until analysis.

Urines were collected into polyethylene bottles containing one thymol crystal as preservative and kept on ice. Each $24 \mathrm{~h}$ urine collection was dealt with separately. The procedure for determination of $\mathrm{N}$ retention was similar to that of Fomon, Thomas, Jensen \& May (1958). A carmine marker ( $30 \mathrm{mg}$ ) was added to the first and last feed of the period. Urine and faeces were stored at $-20^{\circ}$.

\section{Biochemical analysis}

Plasma samples were analysed using the following techniques: albumin by a manual adaptation of the bromocresol green method of Northam \& Widdowson (1967), urea by the Berthelot reaction after enzymic hydrolysis with urease (EC 3.5.I.5) (Kaplan, 1965), transferrin and $\beta$-lipoprotein by radial immunodiffusion (Hoechst Pharmaceuticals, Hounslow, Middlesex), and cholesterol by the Leibermann-Burchard reaction (Gilford Instruments Ltd, 1969). Amino acids contents were determined using a Locarte amino acid analyser.

Alkaline RNase activity in plasma was measured using transfer RNase as substrate (from baker's yeast; Boehringer Corporation (London) Ltd) at a concentration of $4.0 \mathrm{~g} / 1$ in $0.04 \mathrm{M}-\mathrm{Tris}-\mathrm{HCl}$ buffer, $\mathrm{pH} \mathrm{7.4}$, containing $175 \mathrm{~mm}$-sodium chloride (total reaction volume $330 \mu \mathrm{l}$ ). A $5 \mu \mathrm{l}$ sample of standard (I $20 \mathrm{mmol}$ cytidine/l), quality-control or serum was used. After incubation for $\mathrm{I} \mathrm{h}$ at $37^{\circ}$, undigested substrate was precipitated with $2.5 \mathrm{ml}$ lanthanum nitrate-ethanol reagent (Ambellan \& Hollander, 1966). A blank reaction was performed on each test using Tris- $\mathrm{HCl}$ buffer without substrate. The final extinction at $260 \mathrm{~nm}$ was measured and the difference, test-blank, calculated. Activity was expressed in units $/$, where one unit was equivalent to the production of I $\mu \mathrm{mol}$ cytidine $/ 1$ per min, under the conditions of the assay.

Urine was analysed for uric acid-N using the method of Caraway (1955), $\alpha$-amino-N by the method of Goodwin (1970) and urea-N and creatinine-N using standard AutoAnalyzer 
Table I. Results of biochemical measurements for fourteen low-birth-weight infants* in the mid-2nd week of life and during the 3 rd week of life and weight gain during the 3 rd week

\begin{tabular}{|c|c|c|}
\hline 2nd week & Mean & Range \\
\hline $\begin{array}{l}\text { Plasma alkaline RNase (units/I) } \\
\text { Urine urea-N (mmol/kg per } 24 \mathrm{~h} \text { ) } \\
\text { 3rd Week }\end{array}$ & $\begin{array}{r}730 \\
4 \cdot 7\end{array}$ & $\begin{array}{l}512-854 \\
3 \cdot 0-7 \cdot 8\end{array}$ \\
\hline $\begin{array}{l}\text { Plasma } \\
\text { Alkaline RNase (units/l) } \\
\text { Albumin }(\mathrm{g} / \mathrm{l}) \\
\text { Urea (mmol/l) } \\
\text { Transferrin }(\mathrm{g} / \mathrm{l}) \\
\beta \text {-Lipoprotein }(\% \text { adult normal) } \\
\text { Cholesterol (mmol/l) } \\
\text { Essential amino acids } \dagger(\mathrm{mmol} / \mathrm{l}) \\
\text { Non-essential:essential amino acid } \ddagger \S \\
\text { Valine:glycine } \$\end{array}$ & $\begin{array}{c}694 \\
40 \\
3 \cdot 7 \\
I \cdot 85 \\
39 \cdot 5 \\
3 \cdot 4 \\
0.36 \\
2 \cdot 3 \\
0.6 \text { I }\end{array}$ & $\begin{array}{c}487-918 \\
30-47 \\
2 \cdot 2-5 \cdot 2 \\
1 \cdot 5-2 \cdot 5 \\
24-60 \\
1 \cdot 5-4 \cdot 8 \\
0 \cdot 27-0 \cdot 49 \\
1 \cdot 5-4 \cdot 4 \\
0 \cdot 28-0.86\end{array}$ \\
\hline $\begin{array}{l}\text { Urine } \\
\text { Urea-N (mmol/kg per } 24 \mathrm{~h}) \\
\text { Hydroxyproline: creatinine } \$\end{array}$ & $\begin{array}{l}8.0 \\
0.4 I\end{array}$ & $\begin{array}{r}4.3-12.5 \\
0.28-0.62\end{array}$ \\
\hline $\begin{array}{l}\text { N Absorption (mmol/kg per } 24 \mathrm{~h}) \\
\text { Retention } \\
\text { Retention (\% N absorbed) }\end{array}$ & $\begin{array}{l}32 \cdot 5 \\
22 \cdot 4 \\
68 \cdot 9\end{array}$ & $\begin{array}{r}30 \cdot 0-35 \cdot 4 \\
18 \cdot 4-27 \cdot 7 \\
56 \cdot 2-82 \cdot 8\end{array}$ \\
\hline Wt gain $(g / 24 h)$ & 40 & $13-51$ \\
\hline
\end{tabular}

RNase alkaline ribonuclease $(E C 3 \cdot 1 \cdot 4 \cdot 22)$; one unit of activity was equivalent to the production of $\mathrm{I} \mu \mathrm{mol}$ cytidine/l per min.

* For details, see p. 459.

$\uparrow$ As the sum of isoleucine, leucine, valine and methionine as in the Whitehead (1964) ratio.

$\ddagger$ Whitehead (1964).

$\S$ Molar ratios.

methodologies (Technicon Instruments Co. Ltd, 1965, 1969). Hydroxyproline was estimated using the colour reaction with p-dimethylaminobenzaldehyde after extraction with Amberlite CG-I 20 (BDH Chemicals Ltd, Poole) ion-exchange resin (Goverde \& Veenkamp, 1972).

All total N determinations were based on the method of Shahinian \& Reinhold (I97I). For analysis, faeces specimens from each infant were combined, weighed and homogenized with a known volume of water. Portions of these, the $24 \mathrm{~h}$ urine samples and the feeds were analysed in triplicate using urea as the standard for the urine assays (recoveries $98-99 \%$ ) and casein as the internal standard for the faeces and feed assays (recoveries were more variable).

\section{RESULTS}

Table I shows the results of the $\mathrm{N}$ retention, plasma RNase and other determinations in the fourteen infants. As a group they absorbed most of the $\mathrm{N}$ received and retained approximately two-thirds of that absorbed. Generally the infants who retained more $\mathrm{N}$ gained more weight. Table 2 compares various biochemical measurements made during the 3 rd week with $\mathrm{N}$ retention and rate of weight gain. Of the various plasma and urine measurements, plasma RNase and urine urea- $\mathrm{N}$ showed the highest correlations with $\mathrm{N}$ retention. The relationship of plasma $\mathrm{RNase}$ with $\mathrm{N}$ retention is illustrated in Fig. I. Only valine : glycine correlated significantly with weight gain. 
Table 2. Correlation between plasma and urine measurements and $N$ retention, weight gain and plasma RNase in fourteen low-birth-weight infants* during the 3 rd week of life

\begin{tabular}{|c|c|c|c|c|c|c|c|c|}
\hline & \multicolumn{4}{|c|}{$\mathrm{N}$ retention } & \multirow{2}{*}{\multicolumn{2}{|c|}{$\begin{array}{c}\text { Wt gain } \\
\text { (days } 14-21 \text { ) }\end{array}$}} & \multirow{2}{*}{\multicolumn{2}{|c|}{$\begin{array}{l}\text { Plasma } \\
\text { RNase }\end{array}$}} \\
\hline & \multicolumn{2}{|c|}{$\mathrm{mmol} / \mathrm{kg}$ per $24 \mathrm{~h}$} & \multicolumn{2}{|c|}{$\% \mathrm{~N}$ absorbed } & & & & \\
\hline & $r$ & $\boldsymbol{P}$ & $r$ & $P$ & $r$ & $\boldsymbol{P}$ & $r$ & $P$ \\
\hline \multicolumn{9}{|l|}{ Plasma } \\
\hline RNase & +0.67 & $<0.01$ & +0.80 & $<0.001$ & +0.23 & & & \\
\hline Albumin & +0.28 & & NS & & +0.18 & & -0.27 & \\
\hline Urea & -0.33 & & -0.59 & $<0.02$ & -0.12 & & -0.48 & \\
\hline Transferrin & $-0 \cdot 23$ & & -0.32 & & NS & & -0.44 & \\
\hline$\beta$-Lipoprotein & -0.14 & & -0.17 & & -0.23 & & -0.10 & \\
\hline Cholesterol & -0.16 & & -0.19 & & -0.39 & & NS & \\
\hline Essential amino acids & -0.54 & $<0.05$ & -0.61 & $=0.02$ & -0.40 & & -0.43 & \\
\hline $\begin{array}{l}\text { Non-essential : essential } \\
\text { amino acid } \\
\text { Valine glycine }\end{array}$ & $\begin{array}{l}+0.20 \\
-0.28\end{array}$ & & $\begin{array}{l}+0.34 \\
-0.30\end{array}$ & & $\begin{array}{l}+0.47 \\
-0.61\end{array}$ & $=0.02$ & $\begin{array}{c}\text { NS } \\
+0.19\end{array}$ & \\
\hline \multicolumn{9}{|l|}{ Urine } \\
\hline Urea-N & -0.64 & $<0.02$ & -0.89 & $<0.001$ & -0.32 & & $-0.8 I$ & $<0.001$ \\
\hline Hydroxyproline: creatinine & +0.17 & & +0.22 & & -0.22 & & -0.25 & \\
\hline
\end{tabular}

Table 2 also shows the correlation between plasma RNase and other biochemical measurements. Plasma RNase was significantly correlated with urinary urea- $\mathrm{N}$ excretion during both the 2 nd and 3 rd weeks $(r-0.57, P<0.05 ; r-0.8 \mathrm{I}, P<0.00 \mathrm{I}$ respectively).

\section{DISCUSSION}

The results showed a significant positive correlation between plasma alkaline RNase and $\mathrm{N}$ retention: those infants who retained more $\mathrm{N}$ had higher $\mathrm{RNase}$ activities. As urine $\mathrm{N}$ is a major component in the measurement of $\mathrm{N}$ retention it would be expected that those infants who retained most $\mathrm{N}$ would excrete least total $\mathrm{N}$ (and also least urea- $\mathrm{N}$ ) in the urine. The negative correlation between plasma RNase and urea- $\mathrm{N}$ excretion found during the 2nd and 3 rd weeks of life showed this to be so.

Plasma RNase was more closely related to $\mathrm{N}$ retention than any of the other measurements made in the circumstances of this study. In rapidly growing low-birth-weight infants receiving $3 \mathrm{~g}$ protein $/ \mathrm{kg}$ body-weight, it could be used as a reliable measure of $\mathrm{N}$ retention. It is interesting that the greatest correlation found was between RNase and $\mathrm{N}$ retention (\% $\mathrm{N}$ absorbed), the factor determined in experimental animals to assess the 'biological value' of a protein.

In view of the results from other studies it is surprising that the correlation between $\mathbf{N}$ retention and plasma $\mathrm{RNase}$ found here was positive. In adults receiving protein of differing quality and in those receiving anabolic steroids or corticosteroids, as $\mathrm{N}$ balance became more positive, RNase decreased (Albanese et al. 197I): in young children with kwashiorkor, RNase was high before treatment but decreased during recovery (Sigulem et al. 1973; Probhavathi, Mohanram \& Reddy, 1977): in weanling rats as protein intake increased, body-weight increased but RNase decreased (Allison, Wannemacher, Banks, Wunner \& Gomez-Brenes, 1962). In each of these the implication is that the more positive the state of $\mathrm{N}$ balance, the lower the RNase activity. 


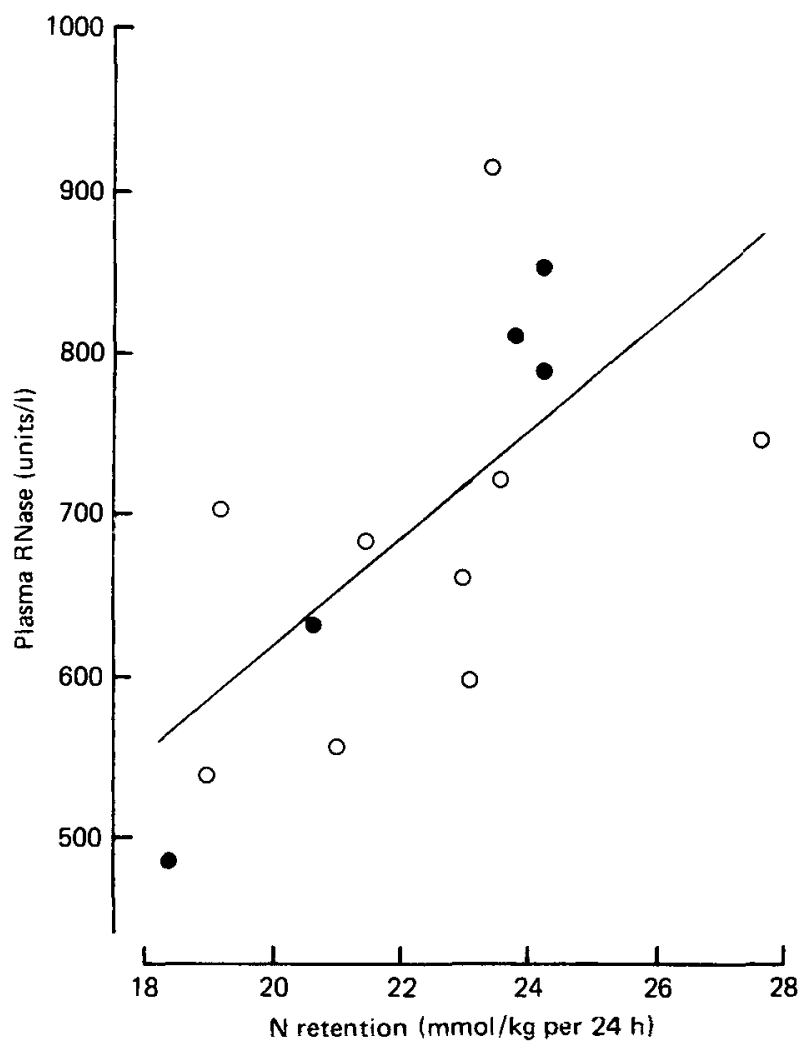

Fig. I. The relationship between plasma alkaline ribonuclease ( $E C$ 3.1.4.22; RNase) (units $/ 1)$ and nitrogen retention $(\mathrm{mmol} / \mathrm{kg}$ per $24 \mathrm{~h}$ ) in fourteen low-birth-weight infants $\mathrm{O}$, preterm; $O$, term light-for-dates; for details, see p. 459) receiving $3 \mathrm{~g}$ protein $/ \mathrm{kg}$ body-weight, during the 3 rd week of life $(r 0.67, P<0.01)$. One unit of activity was equivalent to the production of $1 \mu$ mol cytidine $/ 1$ per min.

There are two possible explanations for this anomaly to be considered. One is that in the newborn infant the relationship between plasma RNase and $\mathrm{N}$ retention is the reverse of that found later in life and in other conditions. The other is that these rapidly growing low-birth-weight infants are marginally short of protein and are therefore demonstrating some measure of protein conservation.

It has been pointed out by Fomon (1974) that, unlike in young children and the adult where most of the protein required is used for maintenance, in the rapidly growing lowbirth-weight infant a very high proportion of the protein requirement can be accounted for by the increase in body protein. This difference could account for the different relationship found between plasma RNase and $\mathrm{N}$ retention in infant and adult; but such a fundamental change seems unlikely.

The alternative explanation seems more probable, that those infants with high plasma free alkaline RNase activity are showing a metabolic response to inadequate protein intake. They were all gaining weight: however there is evidence that weight gain is not the first thing to be impaired in protein undernutrition. Whitehead, Frood \& Poskitt (1971) showed that young children on a low-protein diet continued to grow for a while even though their plasma albumin was beginning to decrease. Therefore, though they are not malnourished a state of 'protein economy' has been created in the infants studied, as a result of their high growth rate. High plasma RNase appears to be associated with the need to conserve $\mathrm{N}$ 
rather than with the state of balance per se. This view is consistent with the results of previous studies and provides a coherent approach to the use of plasma alkaline RNase activity as an indicator of $\mathrm{N}$ metabolism.

H.M.B. held the Mary Crosse Research Fellowship. The authors thank Mrs J. King and Mrs S. Doughty who gave valued nursing assistance and Mrs S. Milner who performed the amino acid determinations; they are grateful to Miss $\mathrm{C}$. Scanlon for secretarial help.

\section{REFERENCES}

Albanese, A. A., Orto, L. A., Zavattaro, D. N. \& de Carlo, R. (1971). Nutr. Rep. int. 4, 151.

Allison, J. B., Wannemacher, R. W., Banks, W. L., Wunner, W. H. \& Gomez-Brenes, R. A. (1962). J. Nutr. 78, 333 .

Ambellan, E. \& Hollander, V. P. (1966). Analyt. Biochem. 17, 474.

Arroyave, G. (1970). Am. J. clin. Nutr. 23, 703.

Caraway, W. T. (1955). Am. J. clin. Path. 25, 841.

Fomon, S. J. (1974). Infant Nutrition, p. 140. Philadelphia: W. B. Saunders Co.

Fomon, S. J., Thomas, L. N., Jensen, R. L. \& May, C. D. (1958). Paediatrics, Springfield 22, 94.

Gilford Instruments Ltd (1969). Clinical Chemical Procedure, no. 0007. Oberlin, Ohio: Gilford Instruments Laboratories Inc.

Goodwin, J. F. (1970). Stand. Meth. clin. Chem. 6, 89.

Goverde, B. C. \& Veenkamp, F. J. N. (I972). Clinica chim. Acta 4I, 29.

Kaplan, A. (1965). Stand. Meth. clin. Chem. 5, 245.

McFarlane, H., Ogbeide, J. M., Reddy, S., Adock, K. J., Adeshina, H., Gurney, J. M., Cooke, A., Taylor, G. O. \& Modie, J. A. (1969). Lancet i, 392.

Northam, B. E. \& Widdowson, G. E. (1967). Ass. clin. Biochem. Tech. Bull. no. II.

Probhavathi, P., Mohanram, M. \& Reddy, V. (1977). Clinica chim. Acta 79, 591.

Shahinian, A. H. \& Reinhold, J. G. (197 I). Clin. Chem. 17, 1077.

Sigulem, D. M., Brasel, J. A., Velasco, E. G., Rosso, P. \& Winnick, M. (1973). Am. J. clin. Nutr. 26, 793.

Smith, S. R., Pozefsky, T. \& Chhetri, M. K. (1974). Metabolism 23, 603.

Technicon Instruments Co. Ltd (1965). Technicon Methodology sheet N-1b. Basingstoke, Hants: Technicon Instruments Co. Ltd.

Technicon Instruments Co. Ltd (1969). Technicon Methodology sheet N-II b. Basingstoke, Hants: Technicon Instruments $\mathrm{Co}$. Ltd.

Whitehead, R. G. (1964). Lancet i, 250.

Whithead, R. G., Frood, J. D. L. \& Poskitt, E. M. E. (197I). Lancet ii, 287. 